\title{
Don DeLillo's White Noise: A Virilian Perspective
}

\section{ABSTRACT}

Don DeLillo's White Noise depicts a world of rapid techno-scientific and economical changes. Paul Virilio's concepts of dromology and speed, as well as his notions of accident and technology, seem to be the most relevant in order to examine a novel centrally concerned with change, speed and technology. This article first offers an analysis of White Noise in the light of Virilio's concept of integral accident in relation to the negative consequences brought about by industrial and technological progress. This is followed by a discussion of the relevance to the novel of Virilio's theories about architecture and space. Finally, Virilio's theories about the replacement of conventional war with pure and info wars are discussed in the context of the central event of the novel. Reading the American writer through the lens of the French theorist can shed light on the enduring relevance of both.

Keywords: Don DeLillo's White Noise, Paul Virilio, accident, info war, virtualization, architecture. 


\section{INTRODUCTION}

White Noise has been subject to many critical analyses. Literary critics have taken up DeLillo's metaphysics (Maltby), Hitler studies and critical whiteness (Engles), consumerism (Osteen), nature and environment (Phillips), and, finally, post-9/11 violence and representation (Devetak). The novel's contribution to our understanding of the contemporary scene from different theoretical perspectives including postmodernism, cultural studies, deconstructionism, and even romanticism has been examined by different literary critics. However, what seems to be missing is a reading of DeLillo's novel through Paul Virilio's views on technology, virtualization and architecture. As this novel depicts a world of rapid techno-scientific and economical changes, Virilio's concepts of dromology and speed, as well as his notions of accident and technology, seem to be the most relevant in order to examine a novel centrally concerned with change, speed and technology. As such, this article offers a detailed analysis of Virilio's concept of "integral accident" in relation to the negative consequences of industrial and technological progress as presented in DeLillo's novel. To this end, we focus on three main spaces in White Noise-the supermarket as a modern urban space, the Boy Scout camp as a military one, and the tourist barn as a natural one-through the lens of Virilio's theories about architecture and space. Also discussed are Virilio's theories about the replacement of conventional war with pure and info wars epitomized by the menace of the toxic spill in the novel and its coverage in the media.

To say more about the relevance of a Virilian reading of White Noise, we should highlight the common ground between the American writer and the French theorist. DeLillo explores contemporary issues such as technology, terrorism, media, the ubiquity of images, virtuality and environmental catastrophes. The contention of this article is that considering the work of DeLillo in the light of Paul Virilio's views on some seminal aspects of modern times-particularly those on images, virtual vs. actual reality, speed and technology - can enhance our understanding of it. Paul Virilio's work is particularly significant here because it voices all these concerns, and more. Moreover, in Virilio all these issues/aspects of the contemporary scene are addressed in relation to each other in the light of a unified body of theorization of the history of human civilization. Thus, Virilio's comprehensive approach can more sharply focus an analysis of a novel which is, like DeLillo's oewvre generally, profoundly concerned with the making of contemporary American society. Reading White Noise, we can find almost exact fictional analogies for some of Virilio's views about aspects of the contemporary scene, especially in relation to its speed and image-saturation. 
The narrator of the novel is Jack Gladney, a professor in Collegeon-the-Hill, living in a small town. Obsessed with death, both Jack and Babette, his current wife, often wonder which of them is going to die first. The novel's plotline revolves around two major events: a toxic spill prompting the evacuation of all houses in the town, and Jack's discovery of Babette's betrayal for getting a drug she thinks would relieve her fear of death.

\section{ACCIDENT ANd Pure War}

As a theorist focusing on the history of civilization (considering it through its main ingredients: war, architecture, technology, speed), Virilio has frequently emphasized the importance of the notion of speed and accident as its corollary. To him, the mind-boggling progress of technology, the fast way in which images and news are reported and received in the highly competitive world of news make dromology the systematic study of speed as the motor of history the defining science of our era. Dromology, a term derived from the Greek dromos meaning "race" or "racecourse," is thus the science of speed. Virilio explains:

Speed enables us to see. It does not simply allow you to arrive at your destination more quickly, rather it enables you to see and foresee. To see, yesterday, with photography and cinema, and to foresee, today, with electronics, the calculator and computer. Speed changes the world vision. (Politics 21)

In Virilio's conception there are important epistemological and ontological consequences to the pervasiveness of speed in the modern world. Speed has changed the very perception of man and thereby his mode of being in the world.

White Noise is also centrally concerned with speed. Jack's and Babette's fear of death, for instance, can be fruitfully explained through Virilio's views on speed and time. At issue here is velocity and its correspondence to Virilio's notion of acceleration in relation to time. The overall argument is that Jack's life and almost all the events in the novel are very much affected by speed and technology as a consequence of speed. Fearing death, Jack and Babette aspire to escape from speed-both in the sense of the frenzied pace of modern life and the speed with which death approaches themin different ways (shopping; seizing the day; drugs magically offered by science; getting lost in virtuality, in the forgetfulness-inducing dream world of images, in the "white noise" of media). Here is one instance. 
"Let's enjoy these aimless days while we can, I told myself, fearing some kind of deft acceleration," says Jack (DeLillo, White Noise 18). However, Jack is clever enough to know that the "carpe diem" remedy is no more than a cold comfort. "All plots," including those of our lives, "tend to move deathward," he reflects (26). For, this "mov[ing] deathward"-for Jack and Babette, for mankind, for the planet-is ever accelerating; things are "heating up" critically (one more sense of "white noise").

A corollary of speed-centered technology is accident. By "integral accident" Virilio means that the potentiality of accident is hidden in any technological means. As he elaborates in an interview: "accidents are a revelation of science and technology's original sin. Science and technology are flawed-in the same way that we are" (Virilio, "The Art of the Motor" 154). The central event of the novel is an ecological disaster caused by the failure of the technology of transportation (the derailing of a tank car carrying toxic chemicals). After the accident, people have to evacuate their houses which are marvels of convenience. It is as if technology was negating itself. Accidents, for Virilio, evidence human vulnerability in the face of the very technology which is supposed to empower.

The misuse of Dylar as a highly advanced psychopharmaceutical drug by Willie Mink, the Dylar project manager, is another example of the debunking of the idealistic view of technology. Technology which was meant to civilize humans ironically has the potential to revive savage instincts. Thus the pill's side effects on both Babette and Willie Mink exemplify Virilian accident. "I forget names, faces, phone numbers, addresses, appointments, instructions, directions," Babette complains (DeLillo, White Noise 52). Later on, in the scene of his confrontation with Willie Mink, to test the side effects of Dylar on Mink, Jack utters the words "falling Plane" only to find that the man "kicked off his sandals, folded himself over into the recommended crash position ... performed the maneuver automatically, with a double-jointed collapsible dexterity, throwing himself into it, like a child or a mime" (309-10). The drug not only causes forgetfulness, it makes the user confuse words with what they refer to. Moreover, Jack's resorting to violence, his attempt to kill his wife's seducer, provides more evidence of the Virilian idea that barbarism is the integral accident of technology. This is what Virilio has always warned about.

Virilio's insightful views about the actual uses made of science-the destructive technologies-sound dismayingly pessimistic. Historically, technology and science are sources of progress. Ironically, however, they are also, historically, the means of destruction. Virilio reflects on the issue thus: 
The civilization or militarization of science? If truth is what is verifiable, the truth of contemporary science is not so much the extent of progress achieved as the scale of technical catastrophes occasioned. Science, after having been carried along for almost half a century in the arms race of the East-West deterrence era, has developed solely with a view to the pursuit of limit-performances, to the detriment of any effort to discover a coherent truth useful to humanity. (Information 1)

The nature of modern science/technology and its uncanny relation to actual life is a seminal concern in DeLillo's fiction too. One of the characters in White Noise, Heinrich, seems to be Virilio's voice in this regard: "What good is knowledge if it just floats in the air? It goes from computer to computer. It changes and grows every second of every day. But nobody actually knows anything" (DeLillo, White Noise 148-49).

The acceleration of events in contemporary life and the consequent accidents is a major concern in Virilio's work. However, what is far more interesting for Virilio is another aspect of accident. Thanks to the fast technologies of communication, accidents are no longer confined to a specific place or time: the local has become global due to virtualization and media. "With the technologies of general interactivity," Virilio urges, "we are entering the age of the accident of the present. .." (Open 14, emphasis in the original). Consider how in White Noise a local accident is mediated and turned into a global one through its media coverage: "The radio calls it a feathery plume" (DeLillo, White Noise 111); "The movie wasn't sure what it does to humans" (111). Though the event proves to be an accident, a technology-generated one, it is blown into one with global impact through the media coverage it receives. Also interesting here are the myriad reports of the names and the subsequent effects attributed to the event in the media. "They're not calling it a feathery plum anymore," Babette tells Jack, adding that it is now called a "black billowing cloud" (113). This naming by media continues until "airborne toxic event" is decided on as the appropriate name (117). This multiplicity of data can also be seen in the media reports of the effects of exposure to the toxic matter, ranging from "nausea, vomiting, shortness of breath" to "the sense of déjà vu" (116). The reality-shaping quality of media is facilely welcomed by the characters in the novel. For instance, Denise, who suffers from nausea instead of experiencing the sense of déjà vu, is said to be "showing outdated symptoms" by Heinrich (117). Virilio observes that "the reality of information is entirely contained in the speed of its dissemination" ("The Art of the Motor" 156). The faster a piece of information spreads, the greater its chance to be accepted as real. Hence, reality is defined to the degree it exists within the media. Although many 
catastrophes occur in India, for instance, as there is no "film footage" and no recording except for "three lines in the newspaper," they are treated as if they have not actually happened (DeLillo, White Noise 66). This colonization of the mind by media can be seen as an inevitable consequence of the high pace of communication technologies. As Guy Debord asserts, it is technology, by the way of the mass media, which seems to "cause a world that is no longer directly perceptible to be seen" (qtd. in Olster 80). That is, media makes us apprehend the world through a set of images and representations separated from their referents and subject to the political whims of their manufacturers. Along the same lines, media in White Noise is presented as a kind of inhuman organism intimating Virilio's idea of a controlling technological tool operating freely in governing minds. In the contemporary era, virtual images of the real have usurped the authority of the real.

The toxic accident provides a good illustration not only of Virilio's idea of accident but also of his reflections on pure war. Virilio explains to Armitage that in the time of the Cold War and the rationale of atomic discouragement, the very idea of refinement sounds grotesque because there is always the possibility of war:

[Pure war] is a war of a single utterance: Fear! Fear! Fear!. . . During Second World War you had resistance against the Germans who invaded France. During the 1960 s and 1970 s there were resistance ... not against an invader, but against the military-industrial complex, that is against the invention of ever crazier sorts of weapons, like the neutron bomb. . . It is resistance against science. (Armitage, "From Modernism” 28)

Virilio's point is that the real menace now is militarized science. DeLillo presents contemporary society facing this unprecedented menace. Expressing her anxieties about a "cloud-eating microbe" which has been "conjured" to eradicate the pollution caused by the toxic accident, Babette tells Jack: "Every advance is worse than the one before because it makes me more scared" (DeLillo, White Noise 161). "The greater the scientific advance, the more primitive the fear" (161), Jack responds in agreement. Virilio's critique - his notion of "total war"-applies here, as the distinction between war time and peace time is blurred and the whole society seems to have changed into a battlefield under the influence of permanent technological deterrence. "The drift towards total war in the twentieth century has multiple consequences for twentieth-century civilization. It deepens the colonization of the social by the military so that distinctions between the 'civilian' and the 'military' become blurred," Luke and Tuathail observe (367). The lack of distinction between states of war and peace will 
challenge not only the question of territory but also that of identity. This is what Virilio means by talking of society as in a perpetual state of war: "all of us are already civilian soldiers, we don't recognize the militarized part of [our] identity" (qtd. in Cooper 119). Indeed, the ubiquitous menace results in the rise of a state of total war or pure war that affects the very mode of life and being in the world. In the novel, evacuation of all places of residence, the sirens screaming out, and Babette's hysterical rush echo Virilio who stresses that "there is no state of peace" (qtd. in Redhead 17) and no end to the World Wars.

Ian James maintains that in order

to understand the manner in which war is present in peacetime, or, more precisely, the manner in which the boundary which separates war and peace is in reality permeable, Virilio highlights the key role played by the concrete bunkers, both in the military and the political imagination of Nazi Germany and in the more general history of warfare and fortification. (73)

In this respect, the Boy Scout camp in the novel, as the secure place for the townspeople, exemplifies Virilio's theories about the role of the bunkers. In line with his general theorization of the essential link between war and architecture in different eras of human history the militarization of space Virilio postulates that architecture is an open book which helps us realize the significance of war in human societies throughout history. There are, in his account, war narratives interwoven into the fabric of every building. "Defensive architecture is therefore instrumental, existing less in itself than with a view of 'doing' something: waiting, watching, then acting or rather, reacting," Virilio asserts in Bunker Archeology (43). Thus, in this sense, the evacuation center, though "abandoned" according to the voice in the radio (DeLillo, White Noise 119), as a bunker-like structure is "instrumental" since it provides a haven for the Blacksmith's citizens against the ever-prevailing threats of modern times. Here is the description of the place:

We were in a large barracks, one of three such buildings at the camp, and with the generator now working we were fairly comfortable. The Red Cross had provided cots, portable heaters, sandwiches and coffee.... The place was crowded, still quite cold, but the sight of nurses and volunteer workers made us feel the children were safe. (129)

Blacksmith is a suburban area. Jack describes the place thus: "Blacksmith is nowhere near a long city. We don't feel threatened and aggrieved in quite the same way other towns do. We're not smack in the path of history and 
its contaminations" (85, emphasis added). At issue here is the nativity of the idea of the town's security against any threat. What we have here is clearly an instance of the idea of pure war, the imminence of war even at peace time. Pure war, thus, is an integral part of life in a technological capitalist society. As for Virilio, "the fortification answers to the accidental, the dual between arms and armor leaves its mark on the organization of the territory by progress in its means and methods, by the potentialities of its invention-war is thus present in peace-time" (Bunker 42).

\section{VIRTUALIZATION}

Virilio holds that war in our time does not depend solely on weaponry and fighting but also, and even more importantly, on how it is accounted for and depicted in the media. In this regard the toxic accident in DeLillo's novel, dubbed "the airborne toxic event," could be counted as an instance of Virilian pure. The news coverage of this disastrous event in the media reflects the relationship between accident, war, and virtualization in Virilio's theories.

Speed, for Virilio, is not just about transportation vehicles; at stake here are all fast means of communication: the media. The ubiquitous presence of TV and radio sets throughout the novel and the fact that characters heavily rely on the news for analyzing the phenomena illustrate Virilio's point about virtualization as the "logistics of perception" and politics. Virilio states that the "logistics of perception can, for example, be linked to the phenomenon of private detectives, to tele-surveillance, and to the phenomenon of 'watching-at-distance'." "The logistics of perception," he concludes in an interview with Armitage, "are thus highly political" ("Kosovo W@r” 187). In fact, the virtual sphere is employed as a means to form a collective understanding of events; it presents its own doctrine of deterrence and security, which turns out to be that of gradually thinking for people. The media in White Noise provide the Blacksmith residents with an arsenal of images and possible side effects of the toxic event, shaping the characters' conception of and feelings about it. First of all, they provide a label for it, calling the catastrophic accident "the airborne toxic event." The mediatic dubbing turns the drab-sounding local accident into a highly dramatic phenomenon. Paradoxically, the word "event" for accident also robs the happening of its menacing potential. The label is an apt one for the process of virtualization launched by the media. Also relevant here is Virilio's anxiety about using technology as a means of controlling people. As Virilio points out in an interview with Armitage, this is another version of a "war model." "The war model is a method of total control over a territory 
and of a population. The aim is to have total control of the population, to bring a whole region or a continent into subjection, through radio, telephone" ("From Modernism" 45). According to Virilio, it is the new media and communication technologies which have made it possible for the menace to be seen, heard or read about, to be felt immediately. Hence, there is the threat of instant annihilation and the possibility of instantly being informed about this threat, all made possible through virtual space of new technologies. The following passage of the novel on Jack's infection with chemicals after the toxic accident in which he sees "computerized dots that registered [his] life and death" (DeLillo, White Noise 140) illustrates this Virilian idea. The computer operator of SIMUVAC who is responsible for making data profiles of the people in the camp explains to Jack how his identity is a virtual technology-bound construction:

Gladney, J. A. K. I punch in the name, the substance, the exposure time, and then I tap into your computer history. Your genetics, your personals, your medicals, your psychologicals, your police-and-hospitals. It comes back pulsing stars. This doesn't mean anything is going to happen to you as such, at least not today or tomorrow. It just means you are the sum total of your data. No man escapes that. (141)

The virtualization discussed by Virilio of course suffuses contemporary life, turning people into "the sum total of [their] data." Also, we realize that the evacuation after the chemical spill is based on this very SIMUVAC, a "state program" which mounts practice evacuations by using real evacuations as models (139).

Another good example in the novel occurs when Babette, Jack's wife, appears on television while the rest of the family is watching. It seems that the family has not expected to see her on TV. The scene depicts them struggling to come to terms with the fact that virtualization has invaded reality. Jack describes the scene thus:

The face on the screen was Babette's. Out of our mouths came a silence as wary and deep as an animal growl. Confusion, fear, astonishment spilled from our faces. What did it mean? What was she doing there, in black and white, framed in formal borders? Was she dead, missing, disembodied? Was this her spirit, her secret self, some two-dimensional facsimile released by the power of technology, set free to glide through wavebands, through energy levels, pausing to say good-bye to us from the fluorescent screen? (104)

The only one who immediately responds to Babette's mediated and virtual self is Wilder, the family's toddler, who approaches the set and 
touches "her body, leaving a handprint on the dusty surface of the screen" (105). Babette's odd course in posture further illustrates the dominance of the virtual over the real sphere. It is the virtual space (here the TV) which controls this practice. People learn how to appear, to embody different postures and take on various positions from the virtual territory of the electronic media. "If you go one step further, then you discover what is the real project of today: the 'media building,' where the facades have morphed into screens," Virilio comments on the increasing dominance of virtual sphere over geo-sphere in his interview with Ruby (64).

As Olster states, "the characters in White Noise are quite willing to place themselves under the control of others" (86). Babette, for instance, recognizes that "people need to be reassured by someone in a position of authority that a certain way to do something is the right way or the wrong way" (DeLillo, White Noise 171-72). Her posture instructions to old people confirm her attitude. However, it seems that the most cogent authority in the world of the novel's characters is not a person living in a physical sphere but a thing dominating the virtual realm electronic media perhaps because unlike written forms of media, TV and radio do not demand literacy as a prerequisite. ${ }^{1}$

The elimination of the difference between virtual reality and actual reality is a notion amply discussed by many contemporary thinkers such as Jean Baudrillard and Virilio. DeLillo has also frequently addressed this notion in his fiction. A classic example in the novel under discussion is the scene in which Jack's son does not trust that it is raining because he has heard on the radio that it would rain later that night. Another good example is the scene of Babette on TV discussed above. Also relevant is the point that the distinction between media objects and media watchers is blurred. A revealing example is the scene where Jack sees the image of himself and other members of his family reflected in the mirrored walls within the supermarket: "I kept seeing myself unexpectedly in some reflecting surface . . . Brightness settled around me . . Our image appeared on mirrored column, in glassware and coherence, on TV monitors in security rooms" (84). The media addicts are also turned into media subjects.

A corollary of this virtualization, according to Virilio, is that the reality entering the mind is "a degenerate reality in which speed prevails over time and space, just as light already prevails over matter, or energy over the inanimate" (Vision 72). At issue here is how virtual time and space can obscure reality and how phenomena are not defined objectively but

1 This is of course a recurring motif in DeLillo's fiction. The following quote from Underworld is typical: "Whoever controls your eyeballs runs the world" (530). 
as one perceives them. In this respect, virtualization becomes a feature of technology, one obscuring and redefining reality. Germain comments:

Transposed into Virilian terminology, this means that reality is ultimately a function of speed. But when reality is perceived as dependent on speed there emerges the possibility of multiple realities based on variances in the relative motion between the perceiver and the perceived. (77)

The "Toyota Celica" scene in the novel illustrates the uncanny impact of virtualization on life in contemporary times. In part two of the novel, the Gladney family takes shelter in a local barracks from the toxic cloud of the chemical spill. As Jack watches his children sleeping, he recounts a visionary moment:

Steffie turned slightly, then muttered something in her sleep. It seemed important that I know what it was ... I sat there watching her. Moments later she spoke again. Distinct syllables this time, not some dreamy murmur-but a language not quite of this world. I struggled to understand. I was convinced she was saying something, fitting together units of stable meaning. I watched her face, waited. Ten minutes passed. She uttered two clearly audible words, familiar and elusive at the same time, words that seemed to have a ritual meaning, a part of a verbal spell or ecstatic chant.

Toyota Celica. (DeLillo, White Noise 154-55, emphasis in the original).

What is expected here is a revelatory utterance. However, it seems that DeLillo is mocking the traditional visionary moments and ironically questioning the possibility of such moments in a postmodern culture. At issue here is what concerns Virilio: the invasion and colonization of the human body and mind by technology. Virtuality has permeated not only the public sphere but also the individual unconscious.

One can also find the precedence of the image over reality in "the most photographed barn" scene, which is also probably the most frequently quoted and commented upon passage in the novel. The scene is a good representation of what Baudrillard has shrewdly termed the hyperreal state or simulation, over which Virilio prefers the term virtualization and substitution. Early in the novel, we are introduced to the most photographed barn in America, a tourist attraction that draws amateur and professional photographers from around the country. As Jack and his colleague, Murray, watch other people taking pictures of the barn, Murray claims that "no one sees the barn," because "once you've seen the signs about the barn, it becomes impossible to see the barn" (12). In a Virilian reading of the scene, all visitors to the barn contribute to the diminution 
and "desertification" of the first-hand and direct experience of the barn and even become "part of the aura" (13) using their own photographic equipment. In this situation, virtual images and representations replace the real; the object of representation declines in importance as the virtual takes over. Virilio explains this situation in the following words in his interview with Joubert and Carlut:

Every real image has a dual identity. We cannot compare a virtual image with a real image. Philosophically it must be compared to the existing image: the real is composed of the existing image and virtual one.... The virtual image is ... the mental image. Thus I think there is a shift in the supremacy, in the primacy of the real image, in favor of the virtual image. In the past, the opposite was true. (125-26)

It is in reference to this triumph of virtuality over reality that Murray comments on the visitors' inability to conceive the true nature of the barn: "What was the barn like before it was photographed?" (DeLillo, White Noise 13). A contemporary theorist whose theorization of virtualization is in many respects comparable to that of Virilio is Baudrillard, the figure most frequently associated with the dominance of the simulacra, the copy without an original, to which this loss of the real leads. He mentions nostalgia as one of the consequences of this state of affairs: "when the real is no longer what it was, nostalgia assumes its full meaning" (6). Murray's nostalgic bemoaning of the erosion of the sense of reality is to be understood in such a context.

Also relevant to "the most photographed barn" scene in the novel is Virilio's reflection on the relationship between architecture/space and perception. To Virilio, human experience is inextricably tied up with bodily movement and positioning. Space affects vision and the body at the same time. Space and environment function as a medium through which perception of reality becomes indirect, secondary, and even incomplete because the world arrives to us in relation to space and surroundings, as Husserlian phenomenology suggests. Thus, space does not just stand in relation to situation, but the information absorbed also comes through that medium. The road to the barn and even the barn itself is replete with the pictures of the barn taken by visitors. This image-covered structure of the barn provides its visitors with a mediated and indirect perception of its own reality: "We're not here to capture an image, we're here to maintain one," Murray comments ironically (DeLillo, White Noise 12).

A distinguishing fact about the Gladneys in White Noise is that "the sense of union they instill no longer depends on physical proximity"; as Olster continues, 
the Friday night gathering, with Chinese take-outs that join Jack and his wife Babette's children from various marriages into a blended whole also join the resultant Gladney family to families all over the country by the way of the television shows they watch while eating. (83)

This confirms Virilio's observations about 'telepresence" as one of the corollaries of virtualization. Due to technological progress and virtual space expansion, there is no need for physical and face-to-face interaction any more. "One can be here and to act somewhere else at the same time," Virilio says in an interview with Kittler (98). Though this situation is profoundly disturbing to Virilio, Jack feels that his life is blessed by the automated teller machine as a technological device. This epitomizes the telepresent condition; for the ATM transactions that Jack uses to check his personal holdings link him to people all over the world by the way of a "mainstream sitting in a locked room in some distant city" (DeLillo, White Noise 46). Linked by technology in this manner, Jack feels that his life is desirable:

I went to the automated teller machine to check my balance. I inserted my card, entered my secret code, tapped out my request. The figure on the screen roughly corresponded to my independent estimate... Waves of relief and gratitude flowed over me. The system had blessed my life. (46)

The illusion that life is blessed by virtue of technology (the white noise of electronic devices) is ironically described in terms of "waves" ("waves of relief and gratitude"); later these are waves of pollution from the spill of the toxic chemicals that make Jack's life hell. Also, generally, Jack's and Babette's lives are affected by "waves" of anxiety (about aging, social status and, above all, death) which are only momentarily fended off by the "waves" of the media, telecommunication and other technological devices. The novel, then, illustrates the uncanny status of technology as the very source of contemporary angst misrecognized as one of blessing.

\section{ARCHITECTURE}

Virilio's interest in architecture has its roots in his preoccupation with studying the German bunkers made during World War II in France. Yet as a Husserlian phenomenologist, he thinks of space as a medium through which human perception in relation to bodily movement is achieved. As James explains, to Virilio, "spatiality is inseparable from our capacity to sense, touch and see within the context of a specific bodily orientation" (12). DeLillo's depiction of architecture and urban spaces in White Noise can also be fruitfully read through the lens of Virilio. 
Virilio believes that architecture and environmental space reveal the ideology and tell the story of different eras. We have already discussed the turning of the supposedly more natural structure of the barn into an artificial/virtual space, as well as the turning of the Boy Scout Camp into a bunker-like shelter, a militarized space. Generally, the architecture and environs described in DeLillo's novel can be said to exemplify Virilio's theories about the designing of space based on military requirements the bunker ideology as well as the prevailing tendencies toward consumerism and virtualization. If, as Virilio suggests, space tells us about the spirit and culture prevailing in each era, then it is no surprise that the image of the students and their vehicles in the opening scene of the novel as a stream weaving through the landscape implies an assembly-line or machineoriented culture to which the students belong. Moreover, their numerous consumer products emblematize the ascendency of consumerism:

The station wagons arrived at noon, a long shining line that coursed through the west campus. In single file they eased around the orange I-beam sculpture and moved toward the dormitories. The roofs of the station wagons were loaded down with carefully secured suitcases full of light and heavy clothing; with boxes of blankets, boots and shoes, stationary and books, sheets, pillows, quilts; with rolled-up rugs and sleeping bags; with bicycles, skies, rucksacks, English and Western saddles, inflated rafts . . . the stereo sets, radios, personal computers; small refrigerators and table ranges ... hairdryer, styling irons; ... onion and garlic chips, fruit chews and toffee popcorn. (DeLillo, White Noise 3)

The landscape of the campus and the surrounding area is supposedly natural (though it is already designed space, suburban space). The naturelike environment, however, is turned into a festive, even carnivalesque, scene of the triumph of consumerism.

Virilio observes that urban spaces and architectural structures in each era reveal the dominant ideology of that era. As such, shopping areas are among the urban spaces that feature most frequently in DeLillo's novel. As a modern structure, the supermarket is a site emblematic of the consumerist culture of modern times. It has a profound impact on different aspects of modern life, even that of reading-the ultimate cultural practice. As Christian Moraru notes: "Reading here hinges on nonspiritual activities, 'Eating and Drinking,' the 'Basic Parameters' (White Noise 171). Knowledge, experience, and literacy have lost their original sense and object, and refocus on the superficial world of consumption" (96). "There are," Jack ruminates, "full professors in this place who read nothing but cereal boxes" (DeLillo, White Noise 10); "they scrutinize the small print on packages, wary of a second level of betrayal" (326). This is 
the place for advertisement-stuffed tabloids, porn literature and all kinds of trashy, thoughtless reading. This is the place of ultimate vulgarization, where everything —all human needs, desires, hopes, fears, aspirations—are catered to, are turned into consumer products to be sold. Jack ironically reflects in the last scene of the novel: "Everything we need that is not food or love is here in the tabloid racks. The tales of the supernatural and extraterrestrial. The miracle vitamins, the cures for cancer, the remedies for obesity. The cults of the famous and the dead" (326).

An alteration in the shelves of the supermarket causes disturbance for the consumers: "The supermarket shelves have been rearranged. It happened one day without warning. There is agitation and panic in the aisles, dismay in the faces of older shoppers" (325). This is because in the world of the novel the supermarket is an artificial haven where the characters seek order, meaning, pattern and even spirituality: "This place recharges us spiritually, it prepares us, it's a gateway or pathway. Look how bright. It's full of psychic data" (37), comments Murray. Murray, whom Jack meets as frequently in the supermarket as he meets him on the campus, comparing Tibetans' beliefs about death and afterlife with the charms of the supermarket, reflects further on the significance of such urban shopping spaces: "Here we don't die, we shop. But the difference is less marked than you think" (38). Such spaces are the modern havens, somehow substituting the religious/spiritual spaces like churches.

Moreover, consciousness of place as something that might be geographically and locally identified-as something towards which one could feel a sense of attachment-is eroded by a variety of technological means such as the telephone, television, computer, ATM, etc. Though White Noise was written in the early 1980s when telecommunication technologies such as the World Wide Web were still in the future, it partly reflects what Virilio calls telepresence, a concept referring to the decline of lived spatial existence due to the prevalence of technology. Virilio particularly focuses on the manner in which the images of cinema and television are telepresent, that is, present at a distance or in their absence, whereby the virtual comes to dominate over the actual. He suggests that modern "vision machines" have invented a new way of seeing, that is, vision as mediated through the transmission of radio or electronic waves which have the potential to give us a new consciousness of the world (Lost Dimension 84)). Consider, as an instance, Jack's description of how Denise, his step-daughter, updates her address book: "She was transcribing names and phone numbers from an old book to a new one. There were no addresses. Her friends had phone numbers only, a race of people with a seven-bit analog consciousness" (DeLillo, White Noise 41). In the novel, chief among these technological advancements which are responsible for our transformed perception of 
space is television which according to Jack is the "focal point" of life in Blacksmith (85). This is of course epitomized in the very title word of the novel. The "white noise" of media has, among other things, effected an erosion of a sense of place.

\section{Conclusion}

DeLillo's novels are, as Tom LeClair shrewdly puts it, "both explanatory and mysterious, singular in expression but multiple in meaning, positive and negative in ... connotations" (ix). They are unique in their treatment of "the postindustrial culture ... the age of information and communication" (ix). DeLillo is what LeClair calls a "systems novelist," one concerned with the endangering of "man-planet," the living, intelligent ecosystem, not least by the "reduction of life to entities in motion" (2). Paul Virilio, as a seminal contemporary thinker, is also centrally concerned with such issues. ${ }^{2}$ Dromology, as the arch concept in his theorization, is key to understanding the contemporary human-posthuman-condition, one of the reign of "convoluted systems" of technology, science, communication, war, virtualization — of capitalism in its newest modes and guises.

Dromology also encompasses Virilio's study of technology and accident, as technology's negative aspect, his readings of urban space in relation to social changes and virtualization. In a similar way, DeLillo in White Noise is obsessed with technology, accident and space. DeLillo's literary world lends itself to being read through Virilio's theories because both the American writer and the French theorist are fundamentally concerned with how technology has changed the very mode of life and the character of human perception. (Note how, for instance, the synaesthesia of the title wordswhite noise-masterly expresses the concern with perception, with how it is transformed through waves of energy and data.) The sense of urgency with which they reflect on modern times is rarely paralleled.

2 It is interesting that Virilio is rarely, if ever, mentioned in studies on works of literature in reference to the theorizations of the postindustrial culture. (LeClair's important early study of DeLillo is a case in point.) This is while Virilio's contribution in this regard seems to be no less seminal and urgent than those of figures associated with systems theory-who highlight the importance of the recognition of information in living systems and the rise of information and communication technology, as well as thinkers like Jean-François Lyotard and Jean Baudrillard.

3 The phrase is that of Joseph McElroy, one of the important influences on DeLillo, used in his 1974 essay titled "Neural Neighborhoods and Other Concrete Abstracts.” 


\section{Works Cited}

Armitage, John. "From Modernism to Hypermodernism and Beyond: An Interview with Paul Virilio." Paul Virilio: From Modernism to Hypermodernism and Beyond. Ed. John Armitage. London: Sage, 2000. 25-55. Print.

---. “The Kosovo W@r Did Take Place.” Virilio Live: Selected Interviews. Ed. John Armitage. London: Sage, 2001. 167-95. Print.

Baudrillard, Jean. Simulacra and Simulation. Trans. Sheila Faria Glaser. Ann Arbor: U of Michigan P, 1994. Print.

Cooper, Simon. Technoculture and Critical Theory: In the Service of the Machine? London: Routledge, 2002. Print.

DeLillo, Don. Underworld. New York: Scribner, 1997. Print.

---.White Noise. New York: Penguin, 1985. Print.

Devetak, Richard. "After the Event: Don DeLillo's White Noise and September 11 Narratives." Review of International Studies 35 (2009): 795-815. Print.

Engles, Tim. "DeLillo and the Political Thriller." The Cambridge Companion to Don DeLillo. Ed. John N. Duvall. Cambridge: Cambridge UP, 2008. 66-76. Print.

Germain, Gil. Spirit in the Material World: The Challenge of Technology. UK: Lexington, 2009. Print.

James, Ian. Paul Virilio. London: Routledge, 2007. Print.

Joubert, Dominique, and Christian Carlut. "Paul Virilio." Ed. John Armitage. Virilio Live: Selected Interviews. London: Sage, 2001. 12127. Print.

Kittler, Friedrich. “The Information Bomb: A Conversation.” Virilio Live: Selected Interviews. Ed. John Armitage. London: Sage, 2001. 97-109. Print.

LeClair, Tom. In the Loop: Don DeLillo and the Systems Novel. Urbana: U of Illinois P, 1987. Print.

Luke, Timothy, and Gearoid O Tuathail. "Thinking Geopolitical Space: The Spatiality of War, Speed and Vision in the work of Paul Virilio." Thinking Space. Ed. Mike Crang and Nigel Thrift. London: Routledge, 2000. 360-79. Print.

Maltby, Paul. "The Romantic Metaphysics of Don DeLillo." Bloom's Modern Critical Viewes: Don DeLillo. Ed. Harold Bloom. Philadelphia: Chelsea, 2003. 51-69. Print.

McElroy, Joseph. "Neural Neighborhoods and Other Concrete Abstracts." TriQuarterly 34 (Fall 1975): 201-17. Web. 7 Apr. 2018.

Moraru, Christian. "Consuming Narratives: Don DeLillo and the 'Lethal' Reading." Blooms Modern Critical Views: Don DeLillo. Ed. Harold Bloom. Philadelphia: Chelsea, 2003. 89-105. Print. 
Olster, Stacey. "White Noise." The Cambridge Companion to Don DeLillo. Ed. John N. Duvall. Cambridge: Cambridge UP, 2008. 79-93. Print.

Osteen, Mark. “DeLillo’s Dedalian Artists." The Cambridge Companion to Don DeLillo. Ed. John N. Duvall. Cambridge: Cambridge UP, 2008. 137-50. Print.

Phillips, Dana. “Don DeLillo's Postmodern Pastoral.” Bloom's Modern Critical Views: Don DeLillo. Ed. Harold Boom. Philadelphia: Chelsea, 2003. 117-27. Print.

Redhead, Steve, ed. The Paul Virilio Reader. New York: Columbia UP, 2004. Print.

Ruby, Andreas. "The Time of the Trajectory." Virilio Live: Selected Interviews. Ed. John Armitage. London: Sage, 2001. 58-65. Print.

Virilio, Paul. Bunker Archeology. Trans. George Collins. New York: Princeton Architecture, 1994. Print.

---. Open Sky. Trans. Julie Rose. London: Verso, 1997. Print.

---. Politics of the Very Worst. New York: Semiotext(e), 1999. Print.

---. "The Art of the Motor." The Virilio Reader. Ed. James Der Derian. Massachusetts: Blackwell, 1998.152-65. Print.

---. The Information Bomb. Trans. Chris Turner. London: Verso, 2005. Print.

---. The Lost Dimension. Trans. Daniel Moshenberg. New York: Semiotext(e), 1991. Print.

---. The Vision Machine. Trans. Julie Rose. London: Indiana UP, 1994. Print.

\section{Hossein Pirnajmuddin is Associate Professor of} English literature at English Department, University of Isfahan, Iran. His research interests include Renaissance literature, contemporary English fiction, literary theory, and translation studies.

pirnajmuddin@fgn.uil.ac.ir

\section{Bahareh Bagherzadeh Samani is}

Assistant Professor at English Department, Azad University, Qeshm Branch. Her research focuses on the intersection of theorization of technology and contemporary American fiction.

bahar_samani@iauqeshm.ac.ir 